\title{
The Rush to the Peripheries: Land Rights and Tenure Security in Peri-Urban Ethiopia
}

\author{
Addiswork Tilahun Teklemariam ${ }^{1}$ and Logan Cochrane ${ }^{1,2,3, *(D)}$ \\ 1 Institute for Policy and Development Research, Hawassa University, Hawassa 05, Ethiopia; \\ adihabesha@yahoo.com \\ 2 Global and International Studies, Carleton University, Ottawa, ON K1S 5B6, Canada \\ 3 College of Public Policy, HBKU, Doha 34110, Qatar \\ * Correspondence: logan.cochrane@carleton.ca
}

Citation: Teklemariam, A.T. Cochrane, L. The Rush to the Peripheries: Land Rights and Tenure Security in Peri-Urban Ethiopia. Land 2021, 10, 193. https://doi.org/ 10.3390/land10020193

Academic Editor: Azadi Hossein

Received: 13 January 2021

Accepted: 10 February 2021

Published: 14 February 2021

Publisher's Note: MDPI stays neutral with regard to jurisdictional claims in published maps and institutional affiliations.

Copyright: (c) 2021 by the authors. Licensee MDPI, Basel, Switzerland. This article is an open access article distributed under the terms and conditions of the Creative Commons Attribution (CC BY) license (https:/ / creativecommons.org/licenses/by/ $4.0 /)$.

\begin{abstract}
As the global population continues to urbanize, increasing pressure is put upon urban centers and the carrying capacity of the already built-up areas. One way to meet these demands is horizontal expansion, which requires new lands to become incorporated into urban centers. In most cases, this demand is met by converting peri-urban land into urban land as the urban center expands. These processes of expansion into the peri-urban, however, create tension regarding land use and land rights, and may foster tenure insecurity if not well managed. As in many countries, Ethiopia is experiencing extensive urban population growth and the peri-urban areas at the edge of urban centers are under pressure. This study investigates land rights issues and tenure security conditions of peri-urban farmers in the case study sites of Addis Ababa and Hawassa. The findings reveal that urban expansion into the peripheral agricultural lands and the resulting tenure system change has caused intense perceived tenure insecurity among peri-urban farmers. The range of land rights exercised differs in these two sites, as measured by the property rights analytical framework. Periurban farmers in Hawassa hold weak owner positions, enabling them to exercise thicker rights. However, peri-urban farmers in Addis Ababa hold weak claimant positions, which is slightly above the operational level right of an authorized user. This analysis suggests that the urban development and expansion strategies adopted by the respective city administrations are impacting land rights of the peri-urban farmers and their tenure security, albeit in unique ways, from which lessons can be drawn about how urban expansion policies can be more appropriately designed and implemented.
\end{abstract}

Keywords: farmers; land rights; Ethiopia; peri-urban; tenure security; urbanization; periphery

\section{Introduction}

Countries continue to urbanize, and, with that, there are increasing demands for vertical and horizontal expansion in urban centers, the latter putting pressure on peri-urban areas [1]. In most sub-Saharan African countries, peri-urban areas are undergoing rapid transformation, the processes of which threaten the livelihoods, land rights, and tenure security of peri-urban farmers, as well as impacts related to changes in land use patterns, such as loss of agricultural land and landlessness [2-4]. One of the challenges emerging from horizontal urban expansion undertaken by governments is that such initiatives may not be inclusive of the peri-urban communities. As a result, these communities may be disadvantaged by formal exclusionary urban development programs. These programs end up displacing the original owners/possessors of the land, causing physical, social, financial, and human asset disruption. Evidence from many developing countries shows that peri-urban areas are undergoing rapid transformation due to changes in land use patterns as well as the challenges of these changes relates to land rights, tenure security, and loss of agricultural land because of urban expansion [4-10].

Complicating urban expansion further is the fact that urban expansion in most developing countries is unregulated and unauthorized, resulting in land development activities 
that are not coordinated and result in the emergence of informal settlement [5,11-13]. Thus, the process of peri-urban transformation is associated with contradictions and unintended material conditions primarily related to issues regarding the entitlement of peri-urban lands [14]. The competing interests between different groups: peri-urban farmers, urban dwellers, private developers, speculators, governmental and non-governmental institutions, and informal settlers make peri-urban land contentious and contested, creating tenure insecurity for legitimate landholders [15]. In many cases, these contradictions are inadequately managed by the land use and planning systems, fueling the polarization of interests and exploitation of the peri-urban dwellers [14]. Most scholars agree that such antagonisms are perpetuated by the regulatory void of the peri-urban context, attributing it to the institutional fragmentations between the central/decentralized rural and urban government agencies [16-18]. Other scholars attribute this to the weak management capacity of regulatory systems where the rapid growth of the area has 'outstripped the city authorities' ability to cope' [19] (p. 43). Yet other scholars attribute the regulatory void to the non-recognition of the residents and non-prioritization of the area by the government [20]. In some contexts, there are yet other causes, such as the weakening of the central government due to political or social turmoil. The government, with the aim to suppress social unrest or prevent further chaos, may be forced to leave those areas unregulated.

The trends of urbanization and horizontal urban expansion are also occurring in Ethiopia, where land acquisition/expropriation and the conversion of agricultural land in peri-urban areas to meet urban utilities is raising the above-noted challenges $[5,6,10]$. The conversion rate of agricultural land to urban built-up area is as high as $379 \%$ in Gondar [21], 85\% in Debre Markos, 168\% in Bahir Dar [7], 180\% in Addis Ababa [9], and $293 \%$ in Hawassa [22]. The urban development policy has enabled this trend by stipulating the use of land expropriation to provide land for better development. As a result of this policy prioritization, peri-urban land is put at the disposal of urban utility at the cost of the peri-urban farmers who are highly disadvantaged as a result of the very low compensation rate and minimal attempts made to support those evicted. The experience of expropriation has fostered resentment within the peri-urban community. The 'say no to the master plan' protest in Oromiyaa regional state, which started in November 2015, can be a case in point. This protest resulted in the total annulment of the master plan revision of Addis Ababa (which has aimed to stretch the territorial boundary of the capital to the neighboring peri-urban areas of Oromiyaa region), can be an evidence for these antagonisms. Due to the dynamic nature of the peri-urban area in terms of land use change and the process of expropriation, the area is a land tenure 'hotspot', characterized by the prevalence of high land tenure insecurity $[7,10,23]$.

Broadly speaking, the prevailing condition of peri-urban farmers is one of being pushed away from their land holdings with insufficient compensation within the system, and, thus, being left tenure insecure as a result of the demands and processes related to urbanization. This raises a question: what makes the present land tenure arrangement different from the previous regimes (the imperial regime and the socialist) in terms of ensuring tenure security? Were the promises that justified the adoption of the current land tenure system delivered upon, especially that of rectifying the historical injustice? This is the broader context within which this research is framed in evaluating land rights and tenure issues of peri-urban farmers.

The population of Ethiopia is predominately rural; however, this is changing, as seen in the high urbanization rates. The demands on urban centers to accommodate rising urban populations has put pressure on the peri-urban areas, which is occurring in many Ethiopian cities. While there are researches documenting the expansion of urban areas, very few have focused on the effect that such expansion has on the land rights and livelihood of peri-urban inhabitants $[5,7,8,10,23]$, who, in most of the cases for Ethiopian cities, are farmers whose livelihood relies on land. The purpose of this paper is to address this gap by investigating land rights issues and tenure insecurity conditions of peri-urban farmers. Unlike other studies in the area, the paper analyses tenure security conditions of peri-urban farmers 
by integrating the real and perceived aspects of tenure security. This paper advances our understanding of land rights and tenure security conditions of peri-urban communities in Ethiopia, and peri-urban Addis Ababa and Hawassa specifically. The following section details the methods utilized, after which land tenure in Ethiopia is contextualized, before presenting the findings.

\section{Methods}

In order to capture the distinct land right and tenure security issues of the farming communities in peri-urban areas, this study employed a comparative case study approach using a qualitative research design. For the case studies, peri-urban areas that are tenure hotspots as a result of significant horizontal urban expansion were identified. The selection process involved a two-step process of selecting the specific case study sites. The first step involved selecting the cities. This was done by analyzing demographic and spatial expansion rates, stages of development trajectories (both developing but one old with huge infrastructural development and the other emerging with less infrastructure) areas which are less studied (especially Hawassa), as well as accessibility and familiarity to the researchers. Resultantly, Addis Ababa and Hawassa were selected. Accordingly, Hawassa city has a population size of 357,196, according to the 2015 CSA (Central Stastics Agency) population projection of the city. The city has 157.2 square kilometers of total land area, out of which only 42.07 square kilometer is built up and $32 \%$ of the land is underdeveloped. Thus, with the higher urban population growth rate of $6.1 \%$ [24], the city is the fastest urbanizing in Ethiopia, whereby it is expected to increase its population size by six-fold by 2040, according to the city level population projection [23] and as a result, Hawassa has the highest conversion rate of agricultural land of $293 \%$ [22]. On the other hand, Addis Ababa city is home to more than 4 million inhabitants, constituting $30 \%$ of the total population of the country's living in urban areas. The city also has the highest rural-urban migration accounting for $40 \%$ of its population growth. This makes the city one of the fast-growing cities in Africa, expanding at an exponential rate of 3.2\% per year [25], and it is expected to transform into a mega city of almost 10 million inhabitants by 2037. Trends show that the built-up areas are increasing at a speed of $4-5 \mathrm{~km}^{2}$ per year with an agricultural land conversion rate of $180 \%$ [9,24].

The second step involved identifying the specific peri-urban areas in Addis Ababa and Hawassa, which are highly affected by expropriation for urban utility or informal land transaction due to the extensiveness of the city expansion. Accordingly, Bole sub-city woreda 11 (Bole-Arabsa), and 10 (Cheri) in Addis Ababa and Chefe Koti Jebesa qebelé (herein after Chefe) from the Hawella-Tula sub-city in Hawassa were selected as specific case study sites as indicated in Figure 1 below. 


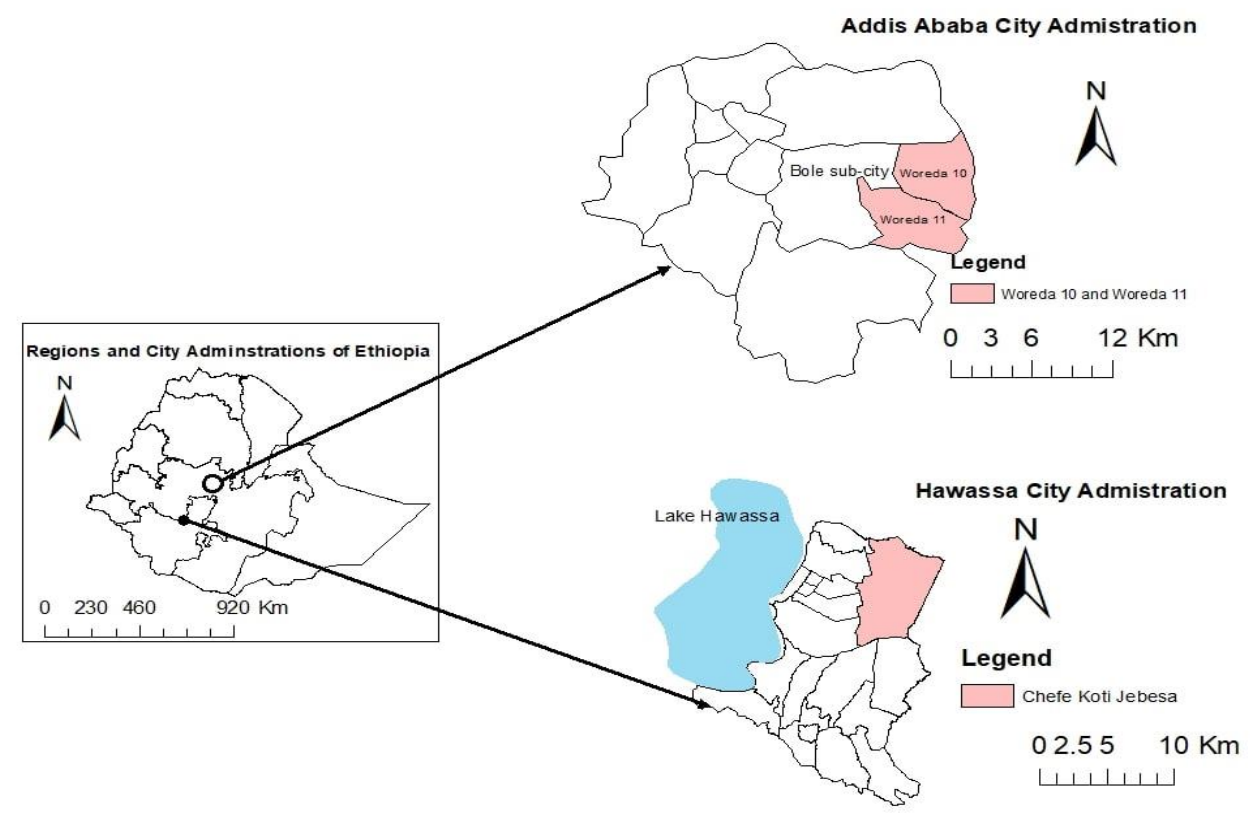

Figure 1. Map of study sites, Addis Ababa and Hawassa.

Since little is known about the land rights issues of farmers in peri-urban areas and because land issues are contested and politically sensitive, a qualitative research design was deemed the most appropriate to obtain reliable data and suited to meet the tended objectives of the study, using the well-developed framework of Schlager and Ostrom [26]. A qualitative research method is appropriate to investigate the quality of the land rights that farmers exercise, and study the distinct de facto practices that shrink or stretch the de jure land rights, because tenure security is not only a matter of process and procedure, but also perception. The choice of method was meant to increase the depth of the investigation by integrating these two components of land rights and tenure security conditions, which can more reliably be obtained via qualitative methods due to the sensitive nature of the questions. The data collection methods were consistent with the qualitative nature of the research. Primary data were collected through semi-structured interviews (with farmers and key informants), via immersion in study areas and participant observation, and through focus group discussions with farmers, which was supplemented by secondary data from different empirical literature. In particular, field immersion and participant observation 'connect the researcher to the most basic of human experiences, discovering through immersion and participation the how and why of human behavior in a particular context' [27] (p. 75). The prolonged stay in the research sites enabled a familiarization with the setting and, most importantly, built trust with the people in the research sites, which in turn helped the researcher obtain robust data.

Semi-structured interviews were employed to investigate the land rights issues and tenure security conditions of peri-urban farmers who were affected by urban expansion. Accordingly, perception indicators are used to measure tenure security (e.g., certainty in the exercise of the rights and anticipation of expropriation) as well as 'real' (administrative and process related) indicators (existence of legal land title, the range/quality of the land rights, both de jure and de facto). To analyze the land rights peri-urban inhabitants have and to assess the change in the benefit streams, this paper uses the property rights analytical framework developed by Schlager and Ostrom [26].

A purposive snowball sampling method was used to identify peri-urban farmers who were affected by urban expansion and land expropriation. The principle of saturation was used to determine the sample size of the participants. To this end, the point of saturation was reached after interviewing 34 farmers in Chefe in Hawassa and 33 farmers in BoleArabsa and Cheri, Addis Ababa. To supplement that data and assess the validity via triangulation, two FGDs (Focus Group Discussions) were conducted in the two study 
sites with peri-urban farmers who were affected by the ongoing urban expansion and expropriation. In the FGDs, a total of 20 affected farmers participated in each FGDs in both study sites.

\section{Ethiopia's Existing Land Tenure Arrangement: The Promises of the Land Policy and the Controversies Arising}

\subsection{The Promises of the Land Policy and the Historical Debate}

After the fall of the Derg in $1991^{1}$, the insurgent forces united in a coalition with ethnic-based parties forming the Ethiopian People's Revolutionary Democratic Front (hereafter EPRDF) and assumed power. The new regime established a federal political system, which restructured the country into a federal state composed of nine regional states drawn along the ethnic lines. ${ }^{2}$ According to the 1995 Federal Democratic Republic of Ethiopia (herein after FDRE) constitution, governmental powers (legislative, executive, and judiciary powers) devolve among the constituencies of the federal system-the federal and regional state governments-enumerated under Articles 51 and 52 of the constitution, respectively. The constitution has also adopted a parliamentarian form of government where the parliament (house of people representatives) has the power of legislation in all matters assigned to the federal state, as per Article 51 of the constitution, which includes the power to enact laws for the utilization and conservation of land (FDRE Constitution, 1995: Art. 51 (5)). Thus, regional states only have the power to administer the land within their boundary in accordance with federal laws.

Before the enactment of the 1995 constitution, the transitional government (1991-1995) terminated many large-sale initiatives undertaken by the previous government, including collectivization, villagization, and grain requisition programs, and began a process of privatizing collective farms and establishing a new economic policy committed partly to liberalize the market [29]. The economic policy adopted by the FDRE government was not a fully free market economy. It was at least in part influenced by Leninist and Marxist ideology. A case in point can be the establishment of the ethnic federalism, the land policy, public ownership of big corporations, such as ETV (Ethiopian Television), EEPC (Ethiopian Electric Power Corporation), ETC (Ethiopian Telecommunications Corporation). The government also heavily regulated the private sector (and continues to do so, for example tariffs on import/export). Despite its effort to liberalize the economy, the transitional government continued the Derg land policy pillar of 'public ownership of land' until a new constitution was put in place. Analyzing the post-socialist transition process, it was highly anticipated by different international organizations, donor agencies, opposition parties, and the people of Ethiopia that the government would adopt private ownership of land under the new constitution [30]. However, when the new constitution came out in 1995, it continued the public ownership of both rural and urban land, to the dismay of many observers [29,31]. As outlined under Article 40(3) of the FDRE constitution, the ownership of both rural and urban land is bequeathed exclusively to the state and the people of Ethiopia.

Consequently, land policy has remained controversial [30] and has triggered debate among different interest groups, including within the EPRDF government itself. According to different observers, the debate is more ideological than substantive from the side of the government compared to those external to it, which focus on empirical data. Gen-

1 The word Derg has become a generic name given to the regime before the EPRDF. However, technically speaking, the Derg was dissolved in September 1987 after an election was held for the national assembly pursuant to the ratified constitution of February 1, 1987. The election brought Mengistu Haylemariam as the president of the newly structured state-proclaimed People Democratic Republic of Ethiopia (PDRE). Hence, this incident marked the transfer of power from the old committee of soldiers, the Derg administration, to the PDRE. However, it was under the same rule, concentrating power in Mengistu's administration leading it to a totalitarian rule [28].

2 Although this is the common descriptor of the federal formation, several states are not drawn around a single ethnic group. In some regions, groups of ethnicities were put together to form a regional state with lines acting as inclusionary lines for diversity in a geographic area (e.g., Benishangul Gumuz, Gambella, Harari, southern nations, nationalities, and peoples), while in others, a demographic majority of a single ethnicity acted as exclusionary lines (e.g., Afar, Amhara, Oromiyaa, Somali, Tigray), although demographically smaller ethnic groups and other ethnic minorities also reside in these regions. Addis Ababa and Dire Dawa are chartered cities. 
erally, there are two antagonistic positions in the debate: the discourse of fairness and protection of individuals arguing for state ownership of land on one side and the discourse of efficiency arguing for privatization on the other [30]. The former is the firm position of the government, as manifested by its incorporation of land issues in the constitution, which would require constitutional amendment for any change to occur. According to the government, privatization fosters the concentration of land in the hands of the few by dispossessing the peasants and leaving them in a destitute situation, which would result in the reemergence of the feudal system and a reversal of the 1975 agrarian reform measures [32]. Public ownership of land was adopted to protect peasants from 'a possible loss of their prized and perhaps irretrievable asset' [33] (p. 230), without which they are incapable of pursuing their livelihood. However, this stance of the government has been criticized for having very little hard evidence to support it [34]. Several studies reveal that peasants are not keen to sell their land if they were made to privately own their land [35-37]. It has also been argued that state ownership of land prevents land market development, and, thereby, discourages farmers' investment on land and encourages the unsustainable use of the land inducing decrease in productivity [38] (p. 1-2).

The government asserted two main justifications for the continuation of land as public property: maintain social justice and ensure historical justice. The government argues that social justice, understood as egalitarianism, could be served by ensuring citizens to have equal and free access to agricultural land and prohibiting the sale and exchange of land. To this effect, the constitution, as well as the federal and regional states proclamations, ensure free access to agricultural land the amount of which provided to peasants is made equal depending on the specifics in the regional states' laws. By making use of periodic land redistributions, the government has opted to guarantee social equality that is said to narrow the gap between the rich and the poor. However, the increasing scarcity of land due to high population density in the highlands where most of the small holding peasants reside results in the manifestation of 'equality of access' as the transfer of land from relatively larger holders to the landless. This resulted in diminution of holding size through a process of unilateral leveling down. According to Rahmato [34], this is a social equality that has come at a heavy price, resulting in equality of poverty. On the other hand, the government claims to serve justice by granting the Ethiopian peasants tenure security by enforcing rural land registration and certification programs ${ }^{3}$ and providing compensation for any investment on land in case of expropriation (article 40(8) of the 1995 FDRE Constitution [39]). Contrary to the government's claim, subsequent research suggests neither land registration/certification nor the compensation schemes enforced ensure tenure security e.g., [40]. In addition, Rahmato [34] argues that state ownership of land by default creates tenure insecurity since the state may use land as a political weapon to politically discipline peasants.

\subsection{A Brief of on the Existing Land Tenure System}

In dealing with Ethiopia's present land tenure policy, the starting point is the constitution, which provides the general framework of the tenure arrangement. As it is clearly indicated in the constitution under Article 40(3), land is a public property, which cannot be owned privately. Hence, rural and urban landholders only exercise usufructuary rights, which include the right to use, rent, and inherit, while entailing the prohibition of sale, exchange, or mortgage of land. The right of mortgage (using the lease right as a security) is exceptionally allowed for urban land leaseholders as per Article 23 of lease holdings of urban lands (Proclamation 721/2011) and for investors who rent rural land from either the government or farmers, as per Article 8(4) of the rural land administration and use proclamation $456 / 2006$. With regard to means of rural land acquisition, sub-Articles 4 and 5 of proclamation 456/2006 state that Ethiopian peasants and pastoralists have the right to obtain land for cultivation and grazing free of charge. Although peasants do not

This was first initiated by a pilot study in Tigray regional state in 1998 and later on supported by the federal government. 
own land, they are entitled to privately own the immovable property that is built and the permanent improvements that are made on the land (sub Article 7). This provision entails that landholders could sell, bequeath and when the right to use the land expires, to remove the property, or transfer the title or claim compensation for it. Moreover, the constitution guarantees protection against arbitrary eviction for peasants. However, if for the purpose of serving the public, the government can expropriate private property 'subject to payment in advance of compensation commensurate to the value of the property' (Article 40(8) of the constitution).

The federal government in exercise of the right conferred under Article 51 (5) of the constitution has issued subsequent rural land administration proclamations, the recently amended one being proclamation no. 456/2005 Rural Land Administration and Land Use Proclamation, which prescribes the country's rural land administration policy. This proclamation delegates regional states with the power to 'enact rural land administration and land use law' that is consistent with it. Accordingly, Tigray, Amhara, Oromiyaa, Afar, Benshangul Gumuz, and SNNP regional states have enacted their own rural land administration and use proclamations.

Although the constitution says nothing expressly or even impliedly about the urban land lease holding system ${ }^{4}$, the country has adopted a dichotomous approach to regulate land-holding systems. Land is either rural or urban. Thus, the legal and institutional frameworks are separate for the rural land holding tenure system and for the urban land leasehold tenure system. The rights emanating thereof are distinct depending on the type of holdings. The individual-land relationship on rural land is constructed on the basis of a holding right for unlimited time, while in the case of urban land individuals exercise a leasehold right for a fixed period of time depending on the type of the lease [6].

As per the currently working land administration practice, although not clearly stated under the law, peri-urban lands fall within the rural land holding system until the full conversion of the area is declared and until the area is fully incorporated within a municipal territory. However, the current scenario of the peri-urban areas entail that they are grey zones where both the rural and urban land administration operate at the same time. Such lack of clarity in the land administration pertain to the unregulated change taking place in the areas as a result of the expansion of the adjacent urban built-up areas.

\section{Analytical Framework for Peri-Urban Land Right and Tenure Security}

Land tenure has diverse definitions. According to the FAO (Food and Agricultural Organization of UN), it is a social relation involving a complex set of rules and institutions invented to regulate social behaviors governing the ways land is owned and used in a given community [41]. A more comprehensive delineation to land tenure is the one provided by United Nations (UN)-Habitat [42] (p. 5):

" ... the set of relationship legally or customarily defined amongst people with respect to land. Tenure reflects relationships between people and land directly, and between individuals and groups of people in their dealings in land".

This definition makes a clear distinction between land tenure and property rights to land. Thus, land tenure defines the means by which land is held or "define how property rights to land are to be allocated within societies" [41] (p. 7). Property rights to land are socially recognized and enforceable interests ${ }^{5}$ in land, or development on it, vested in an individual or group of people [12,42]. Property rights involve the relationships between the right holder, others, and the governance structure that backs the claim [38]. Accordingly, property rights to land articulate "who can do what on a plot of land" [12] (p. 8) or who has

4 The urban land law remains controversial as its authoritative source in the constitution is not clearly established. However, some government officials argue that Article 40(6) "... government shall ensure the right of private investors to the use of land on the basis of payment arrangement established by law ..." "is the source of the urban land law [29].

5 Such "recognized interests may include statutory, customary, or informal social practices, which enjoy social legitimacy at a given time and place" [42] (p. 5). 
the right to enjoy benefit streams that emerges from the use of the land [12,43]. Thus, it is evident that property rights to land do not imply the ownership of the piece of the land rather the enjoyment of multiple benefit streams (bundle of rights) emerging from the use of the land or resource [44]. Such "rights need to be sanctioned by a collective [state or use group] in order to constitute effective claims over the land" [38] (p. 2) and shape societal behaviors. Hence, the extent of the rights within the bundle as well as the mechanism of enforcement of such rights vary within and between tenure systems. Some tenures may have a thicker bundle of rights to offer for the holder while others might have limited ones; some may have a formal/statutory enforcement, while other tenures may have customary or informal enforcement mechanisms.

The other relevant concept is tenure security. It is argued that secure property rights, or tenure security, is central to sustainable economic development as it encourages investment for the sustainable and optimal use of resources [45-48]. Despite its importance, the concept does not have an agreed upon definition. Thus, "there is a great deal of variation in how it is defined and measured" [45]. In an attempt to find a common analytical thread among the different definitions and measures employed, Arnot et al [45], by adopting concepts from Sjaastad and Bromley [49], state that the definitions fall in either of the content or assurance aspects of tenure. Therefore, methodologically, tenure security can be divided in to two: real and perceived tenure security. The perceived tenure security depends on perception indicators as a measure of tenure security. This is particularly the case for those who use assurance/certainty as a concept of defining tenure security $[12,23,41,46,49-52]$. These scholars employ perception indicators like probability of eviction or expropriation, expected time until eviction, uncertainty over changes in government policy, freedom from imposition from outside, and 'probability of extension or renewal of the right [45]. For example, Place, Roth, and Hazell [51], define tenure security as the individual's perception of his/her rights to a piece of land on a continual basis, free from imposition or interference from outside sources, and the ability to reap the benefits of labor or capital invested in land, either in use or alienation. Hence, certainty is in terms of the assurance in exerting the rights and the cost of enforcing these rights should not be inhibiting [51]. Similarly, Bruce and Migot-Adholla [53] (p. 3) defined tenure security as:

" ... the perceived right by the possessor of a land parcel to manage and use the parcel, dispose of its produce, and engage in transactions, including temporary or permanent transfers, without hindrance or interference from any person or corporate entity, on a continuous basis ..." .

Conversely, other scholars depend on the substance/content of the land right to measure tenure security. The duration (length of time for which the land rights are valid) and the breadth of the right are focal points of analysis for such scholars. In this regard, both the quantity and quality of the land rights are held as the basis in defining tenure security [54]. Scholars have used indicators like degree of transferability, protection against eviction or expropriation, legal land title, type of land tenure, method of land acquisition, and duration and range of use rights to measure the real tenure security [45]. The content measures, specifically emphasizing on the range and quality of the land rights, have the tendency of acclaiming the private property regime as it is assumed that it renders tenure security for the owner. However, scholars, such as Lund [55], caution that when duration and extent of rights are used as a measure of tenure security it may imply that private property has the highest tenure security possible as exclusivity creates tenure security for the excluding party and the opposite for the excluded having subordinate rights. More specifically,

“... equating security with transfer rights to sell and mortgage is true for some parts of the world but it is not true in many others. People in parts of the world where there are strong community-based tenure regimes may enjoy tenure security without wishing to sell their land, or without having the right to do so, or having strictly limited rights to transfer" [41] (pp. 17-18). 
Therefore, stronger private property might not mean stronger tenure security, because stronger private property rights might lead to loss of land. Additionally, other factors could affect the assurance of such rights.

With regard to legal land title, in the present capitalist world, there prevails a general understanding among most scholars that an economic pursuit require among other things, an effective and inclusive legal system with clearly defined rules securing rights to property [52,56-61]. In this regard, De Soto [57] argues that a formalized property system recognized in the form of title and registration, among other things, will have the role of ensuring and increasing full tenure security. Even before De Soto, Feder and Noronha [62] argued that the presence of formalized property rights, by eliminating anxiety and uncertainty of expropriation, raise the tenure security of farmers, which encourage them to make long-term investment decisions. However, scholars have produced evidence supporting the claim that legality of tenure is not necessarily a precondition for security $[34,61,63-66]$.

As Arnot et al [45] suggest, there is emerging evidence showing that the content measure of tenure security in some cases leads to a misspecification of empirical estimation. Thus, by following Sjaastad and Bromley [49], Arnot et al [45] note that it is the "assurance aspect of tenures and their impacts on expected benefit streams that relate to concepts of tenure security" [45] (p. 308). To test this assertion and evaluate the performance of the indicators in measuring tenure security as well as to clearly understand the tenure conditions of peri-urban farmers, this research employs multiple factors from both content and assurance aspects to measure tenure security. Accordingly, real indicators (legal land title, the range/quality of the property right exercised) and perception indicators (certainty in the exercise of the rights and anticipation of expropriation) are used. The selection of indicators was mainly based on the proper applicability of the factors on the peri-urban context and their relevance to elucidate the impact of urbanization.

In order to analyze the land rights peri-urban landholders have, and to investigate the change in the benefit streams as a result of the shifting context of the peri-urban land, this study uses the property rights analytical framework developed by Schlager and Ostrom [26]. This approach is the most comprehensive analytical framework because it allows the identification of specific rights a land user holds and what kind of benefit streams or authority such rights confer. Furthermore, it helps to determine the land right status of the holders. Thus, it is an appropriate tool to analyze and compare the distinctive and changing land rights of peri-urban farmers in the two cities.

According to this framework, the land rights consist of five specific attributes, which exist in a group, and are called "bundle of rights". The rights in the bundle are; the right to access, withdraw, manage, exclude, and alienate. The content of the bundle differs in thickness depending on the type of property regime. The framework distinguishes between two types of property rights based on the level of command over benefit streams and resources bestowed upon the right holders: operational level and collective choice property rights [26]. Among the five different levels of actions, ranging from the least authority of access - with a lot of restriction - to the greatest authority of alienation - with less restriction-the operational level comprises access and withdrawal rights (see Table 1). As defined by Schlager and Ostrom, access refers to "the right to enter a defined physical property" and withdrawal refers to "the right to obtain the products of a resource" [26] (p. 250). Collective-choice property rights, in addition to the operational rights, includes management, exclusion, and alienation rights [26]. ${ }^{6}$ Thus, collective-choice rights provide a higher level of command over benefit stream and the actions taken at this level determine and change the operational rules. Table 1 illustrates the distribution of the bundle of rights a right holder exercises, depending on the status he/she holds over the land.

6 Each rights are defined as follows: the right of management is "the right to regulate internal use patterns and transform the resource by making improvements"; exclusion is "the right to determine who will have an access right, and how that right may be transferred" and alienation right is "the right to sell or lease either or both of the above collective- choice rights" [26] (p. 251). 
Table 1. Bundle of Rights Distribution.

\begin{tabular}{ccccccc}
\hline $\begin{array}{c}\text { Level of } \\
\text { Authority }\end{array}$ & Rights & $\begin{array}{c}\text { Authorized } \\
\text { entrants }\end{array}$ & $\begin{array}{c}\text { Authorized } \\
\text { users }\end{array}$ & Claimant & Proprietor & Owner \\
\hline $\begin{array}{c}\text { Operational } \\
\text { Level }\end{array}$ & Access & $\sqrt{ }$ & $\sqrt{ }$ & $\sqrt{ }$ & $\sqrt{ }$ & $\sqrt{ }$ \\
\hline $\begin{array}{c}\text { Collective } \\
\text { Choice }\end{array}$ & Management & $\sqrt{ }$ & $\sqrt{ }$ & $\sqrt{ }$ & $\sqrt{ }$ \\
\hline & Exclusion & & $\sqrt{ }$ & $\sqrt{ }$ & $\sqrt{ }$ \\
\hline & Alienation & & & $\sqrt{ }$ & $\sqrt{ }$ \\
\hline
\end{tabular}

Source: Author's amendment of Schlager and Ostrom [26] (p. 252), Adam [6] (p. 124) and Crewett et al. [38] (p. 4).

The thickness of the right a landholder exercises depends on the type of property regime and the level of authority provided. Thus, property right regimes can describe how the different attributes are distributed among the right holders [6] and the thickness of the attributes of rights determine the level of tenure security. As indicated in Table 1, a person who holds operational level rights cannot exercise full tenure security while the collective-choice rights are held by another person, as the enjoyment of the access or withdrawal rights are dependent on the latter. Hence, as we go down from access to alienation, the level of authority and the extent of rights exercised tends to be high since landholders are provided with wide range of rights. Accordingly, owners feel more tenure secure than other right holders. This is because the quantity of rights exercised by property holder affects the incentivization of individuals, the type of action taken, and the outcomes achieved [67]. In other words, the kind of land tenure system a country adopts defines how the different interests to land or bundle of rights are distributed among interest groups basically government, society, community leaders, and the individual. The extent of the rights bestowed on the individual determine the level of authority the individual have over the land, which, in turn, affects the level of tenure security the individual enjoy. However, other regulatory systems (besides the distributed rights in the bundle, the regulatory systems to protect / safeguard and promote such rights are equally important in promoting tenure security. Thus, the expropriation and compensation legal frameworks in the formal system designed based on the rights and level of authority a landholder exercise determine the rights of the holder and limit the power of the taker. Moreover, the regulatory mechanism in the customary system also have equal importance in securing rights of the members. Accordingly, to measure the range/quality of both de jure and de facto land rights holders exercise indicators were used. These indicators include: being able to cultivate on the land; being able to make permanent improvements on the land (which form the management right); protection against expropriation and, whenever there is expropriation, the right holders are properly consulted, given notice of expropriation and occur within a proper compensating system (accounting for exclusionary authority), as well as being able to bequeath their land and alienate the property they have on the land (which form the alienation right).

\section{Account of the Study Sites}

This study investigated two unique peri-urban locations in Ethiopia. The two study sites are different from definitional point of view of peri-urban land and due to the formalization of land rights. In addition to the rural agricultural lands adjacent to municipal territories, the study included those agricultural lands having rural features, but have already been subsumed within the municipal territory and served as expansion zones. Up until 2011, Addis Ababa had 23 rural qebelés within its administrative boundary. How- 
ever, in 2011, following the revision of the administrative structure of the city, the city was altered to have only city territory, and the 23 rural qebelé structures were dissolved overnight. The rural lands under the previous administrative structure were converted to urban expansion zones. Accordingly, the Bole-Arabsa and Cheri sites, which were rural districts in the previous structure, are now included in the city master plan as expansion zones and reflect peri-urban land that has already been subsumed within the municipal territory. The site in Hawassa, Chefe, reflects both features; it is one of the rural qebelés within Hawella-Tulla sub-city that has been reclassified as part of Hawassa city administrative boundary following the 2005 annexation ${ }^{7}$ of adjacent rural qebelés into the urban administrative boundary. The qebele is predominantly agricultural land governed by the rural land holding system; however, some parts of the qebelé that were informally developed are being included within the municipal territory through regularization measures, and the land governance structure is being changed to the urban lease hold system. The two sites also present distinct features in terms of land right formalization. The land rights of peasants in the Bole-Arabsa and Cheri sites have not been formalized; the peasants do not have certificates of holding. However, they still pay agricultural land tax, which was the only material evidence to prove the presence of holding rights in the previous system before the issuance of land certification. In the Hawassa site, peasants have land certificates for their holdings.

Though the degree of dependency varies, agriculture is the main source of livelihood in the study sites. Particularly in the Bole-Arabsa and Cheri sites, subsistence farming and cattle rearing are the main sources of livelihood. Very few have other means, such as small businesses operating in the area (shops, local bars, and cafes). While in Chefe, the majority of the community members have other permanent means of income generated from renting residential units, which is done alongside small-scale agriculture, mostly as household garden agriculture. The availability of rental units was the result of unauthorized land fragmentation, transaction, and development undertaken by the farmers. Due to this fact, farmers in Chefe are economically better off compared to farmers in Bole-Arabsa and Cheri.

The system of urban land development and the expansion strategies undertaken by the respective municipalities are different in-terms of their relative inclusivity. In Hawassa, the urban development program undertaken by the city administration is relatively inclusive, in the sense that it did not engage the displacement of the local farmers. ${ }^{8}$ With the adoption of "regularization" as a new urban development strategy in $2015[69,70]$, the city administration undertook a campaign to formalize holdings in the informally developed peri-urban areas. The city administration started formalizing farmers' residential holdings in lieu of the urban leasehold arrangement, where most are getting title deeds for $500 \mathrm{~m}^{2}$ residential holdings. In addition, the process of adjusting the settlement pattern to the local development plan is taking place at a relatively slow pace. However, this does not mean that such changes are taking place without public resentment. Most of the farmers are skeptical about the process and fear that it will endanger their holdings, livelihood, culture, and social and psychological makeup.

In Addis Ababa, the urban land development projects are not inclusive and farmers are paying the cost. Farmers are not beneficiaries of the urban development programs taking place in the locality. Land is totally (including the residential plots) expropriated from the farmers upon payment of very small compensation (ranging from 51-54 ETB (Ethiopian Birr $)^{9}$ per $\mathrm{m}^{2}$ area depending on the type of land: agricultural or grazing, respectively). ${ }^{10}$

7 According to Abbink [68], this annexation process under the pretext of urban growth [69] was a political response for the urban voters after the 2005 election land slide victory by the oppositions in urban Ethiopia including Hawassa [70].

8 This is only true for the period after 2015. However, back in 2003 and in the following years, after Hawassa acquired a city administration status as an urban local government (following the commencement of the national urban reform program and the introduction of a decentralized form of self-administration), the city administration expropriated vast farm land with highly contested expropriation procedure and distributed it for urban use [70].

9 Based on the current exchange rate, the values are equivalent to USD $\$ 1.77-1.8$, respectively.

10 This was the amount paid to farmers during my field visit. It has since risen to 60 ETB per $\mathrm{m}^{2}$ equivalent to USD $\$ 2$. 
The farmers are given substitute residential plots that do not take in to account the condition of their livelihood, which was dependent on agriculture. This results in the displacement of farmers and the disruption of their livelihood, as they are no longer able to engage in an agricultural livelihood. Most farmers resent how the city administration is providing them with substitute land because the substitute land given is less quality, in both location and natural setting. For example, farmers are forced to give away their land for a substitute that is far away and/or sloped/gully land. As a result, farmers are detached from their social interactions fostering feelings of disconnection.

With regard to institutional commitment, farmers reported the prevalence of corruption in the land administration institutions in both cities and that this has affected farmers to a great extent. In both cases, due to the corrupt system in the land administration institutions, there were incidences where farmers gave up their rights without redress (especially in Addis Ababa). Most interlocutors reported that injustice is the prevailing condition of their situation. With this general account of the case study sites, the following section presents a comparative analysis of land rights and tenure security conditions of farmers in these two peri-urban areas.

\section{Results and Discussion: Land Rights and Tenure Security in Peri-Urban Context 6.1. Peri-Urban Land Rights and Their Distinct Property Issues}

As it has been shown by different scholars $[2,4,6,15]$, since the peri-urban areas are the receiving ends of urban development they are under perpetual flux, creating considerable challenges to land holding arrangements, land rights, and tenure security. The land rights exercised by farmers in the study sites are different, resulting in distinct property right holders' status. This difference is attributed to the discrete practices of handling urbanization by the two city administrations. This section analyzes the actual land rights exercised by peri-urban farmers and investigates the change in the benefit streams of peri-urban land holdings by using the property rights analytical framework of Schlager and Ostrom [26], see Table 2. The findings are compared with each of the study sites and against the rural landholder positions, developed by Adam [6].

Table 2. Rural landholder positions.

\begin{tabular}{cc}
\hline Land Rights & Rural Landholder's Position \\
\hline Access & $\sqrt{ }$ \\
Withdrawal & $\sqrt{ }$ \\
Management & $\sqrt{ }$ \\
Exclusion & Inheritance and Gift to Family Members \\
Alienation & Strong Proprietor \\
\hline Holder's Position &
\end{tabular}

\subsubsection{Analysis of Land Holding Rights and Holders' Status in Peri-Urban Addis Ababa}

Farmers' settlements in Cheri and Bole-Arabsa were the result of the Derg resettlement and villagization programs. Their land rights emanated from the land distribution, which took place during that period. Farmers have been paying agricultural land taxes and were administered by a peasant association under woreda 28 of Region 14, Zone 03. After the coming to power of the EPRDF, the areas were restructured under rural qebelés, where the rural land administration was in operation. However, in 2011, following the revision of the administrative structure of Addis Ababa, the city was made to constitute an entirely urban territory governed by the urban land tenure policy. Hence, those rural qebelés under the city's previous administrative structure were changed to urban, including the area of the study sites. The revision resulted in the dissolution of the rural land administrative structure and the conversion of the rural areas into expansion zones.

As a result of the conversion of these areas into expansion zones, the farmers' rights to be protected from eviction were compromised and their land rights transformed into 
temporary rights. Due to these changes, farmers do not have rights to engage in activities that permanently develop their land (e.g., constructing house and fence, digging a well, planting permanent trees, and improving/renovating their residential house). There is a very strong control mechanism undertaken by the community policing departments of the respective woredas. The community-policing department carries out site visits to the areas every week. The department has the authority to stop any permanent development being carried out on the land and report the same to the woreda so that the authorities enforce demolition. As a result, it is uncommon to see new developments on land in the areas. The reason the woreda authorities provide for the prohibition of development on land is to avoid additional cost of expropriation as any development on the land raises the rate of compensation. Regarding the compensation payment, there are many reports of late compensation payment for expropriated land. Accordingly, $12(35 \%)$ respondents reported that compensation was paid to them a year after the land was expropriated; while 6 respondents $(18 \%)$ reported that compensation was paid 2 years after expropriation; while another 6 respondents $(18 \%)$ reported that they were compensated 3 years after expropriation. While in three extreme cases compensation had not been paid until the date the data were collected (almost 10 years). The new beneficiaries occupy the expropriated land before the formal procedure of compensation payment was completed. Farmers are forced to give up their holding rights before they are formally reimbursed. Thus, technically speaking, farmers are devoid of their right to exclude others.

Furthermore, the data show that the formal procedure of accrediting beneficiaries of gifts and inheritances were stopped following the administrative structure revision of Addis Ababa. Consequently, rural land administration institutions regulating rural land matters in the city were closed. Since then, farmers give/inherit plots to their family members; however, the beneficiaries are not able to get any formal document to accredit their holding right or pay the land tax in their name. As a result, many of the beneficiaries hold land without formal documents. This raised the level of their insecurities and has the tendency to shift long practices on inheritance.

Table 3 shows that farmers in Bole-Arabsa and Cheri sites have full authority to exercise the operational-level rights (access and withdrawal) while all the collective-choice rights are fully or partially compromised. They have the full right of access, withdrawal, and the right to regulate internal use patterns except for improving land. Thus, according to the property rights analytical framework of Schlager and Ostrom, farmers in Bole-Arabsa and Cheri sites have a weak claimant position. A claimant is one who can exercise the rights of an authorized entrant and authorized user plus the collective choice right of management. Since the rights to develop land and plant permanent trees, which constitute the authority to "transform the resource by making improvements" [26] (p. 251) are banned, peri-urban farmers in Bole-Arabsa and Cheri sites have authority that is beyond the authorities of an authorized user, but less of a 'claimant'. Therefore, they have a 'weak claimant' position.

\subsubsection{Analysis of Land Holding Rights and Holders' Position in Peri-Urban Hawassa}

As stated above, this qebelé is part of the rural Hawella-Tulla sub-city, which was annexed to Hawassa city administration in 2005. Unlike the case in Addis Ababa, the annexed qebelés have remained rural and within the rural land tenure system. This was as a result of the negotiation undertaken between the administration and the community, whereby an agreement was reached to keep the land rural as a prerequisite for the annexation. This was a political decision to secure votes from the newly annexed areas; "assuming that the Sidama would have better political partisanship to the ruling party than the heterogeneous residents of the city" [70]. Thus, the prioritization of the political agenda over the urban development agenda resulted in the adoption of relatively gentle urban development strategies in contrast to those in Addis Ababa. 
Table 3. Bole-Arabsa and Cheri site peri-urban landholder positions.

\begin{tabular}{cc}
\hline Land Rights & Peri-Urban Landholder Positions \\
\hline Access & \\
Mathdrawal & \\
Exclusion & $\begin{array}{c}\text { Cannot develop land and plant permanent } \\
\text { trees but can still regulate other use patterns } \\
\text { until expropriated. }\end{array}$ \\
Alienation & $\begin{array}{c}\text { Government authorities can take land any } \\
\text { time without paying compensation in advance. } \\
\text { Inheritance and gift are limited in practice } \\
\text { (beneficiaries could not acquire documents, } \\
\text { which are relevant to be eligible for } \\
\text { compensation). }\end{array}$ \\
\hline Holder's Position & Weak Claimant
\end{tabular}

Source: Empirical data from Bole-Arabsa and Cheri sites analyzed within the adapted framework of Schlager and Ostrom's [26].

The data from Chefe show that farmers in this area are able to develop their land subject to a special permit issued by the qebelé authorities. A farmer who wishes to renovate or construct new houses has to secure permit from the qebelé, otherwise it might result in demolition. However, a high demand for the construction permit and a corrupt system in the qebelé have costed farmers. According to an interview with a farmer,

"... the qebelé authorities deliberately delay permit decisions to artificially cause caseloads that will enable them collect corruption proceed paid for accelerated decisions. We usually give a minimum 10,000 birr ${ }^{11}$ bribe for a permit. And most of the time their decisions are partial; tend to benefit their close ones [relatives]."

Apart from that, there is no restriction with regard to planting permanent crops and construction for irrigation and wells. Although not completely, some farmers are getting title deeds of urban land holdings for the residential land under their possession.

In addition, the data from Chefe indicate that farmers exercise rights that are not within the framework of rural land holding rights, but relating to urban leasehold rights. The fact that farmers are able to develop land and the enabling conditions adopted by the formal structure (regularization) has enabled farmers to exercise alienation rights. The regularization strategy adopted (the conversion of informally developed holdings into the lease system and issuance of title deeds) by the city administration has encouraged and given confidence to both farmers and potential buyers to engage in informal land transactions. ${ }^{12}$ As presented in Table 4, peri-urban farmers in Hawassa exercise all of the land rights from access to exclusion and the right of alienation, with certain limitations. As a result, farmers' hold a position close to ownership. It is not full ownership because they do not have the authority to sell land without any development.

11 This value is equivalent to USD $\$ 347$.

12 The farmers engage in literal land transactions, except the technicalities they employ, to make the transaction legal. Since the farmers lack the financial resource to construct houses, what they do is-they first sell the land and they negotiate with the buyer to construct a house (usually a mud house) with the supervision and control of the farmer funded by the buyer. That is why we call it a land transaction. 
Table 4. Chefe qebelé peri-urban landholder positions.

\begin{tabular}{cc}
\hline Land Rights & Peri-Urban Landholder Positions \\
\hline Access & $\sqrt{ }$ \\
Withdrawal & (can develop land up on securing permit) \\
Management & "Improvements" on land can be transferred \\
Alienation & through sale or bequest, or gift, or can be used \\
& as a collateral for loan.
\end{tabular}

Holder's Position

Weak Owner

Source: Empirical data from Chefe site analyzed within the adapted framework from Schlager and Ostrom [26].

\subsection{Condition of Land Tenure Security of Peri-Urban Farmers}

This study investigated the condition of tenure security of farmers in peri-urban Addis Ababa and Hawassa. With regard to farmer perceptions, an assessment of the periurban farmers' feelings of certainty regarding their rights over the land they possess and their anticipation of expropriation or eviction were asked. Among the total interviewed farmers (34 in number), in Chefe, 85\% responded that they felt uncertain about their land rights and felt that their agricultural land is going to be expropriated. Learning from the experience of different peri-urban areas around Hawassa city: Dato and Tilte qebelés, where the government has expropriated land from farmers, farmers in Chefe are well aware of the fact that expropriation is inevitable as the city expands and that their agricultural land is going to be expropriated to meet the urban demands. Farmers indicated the fact that the city administrative authorities, together with the qebelé and sub-city administrations, have discussed with them the inclusion of the qebelé into the urban territory. Though it was highly opposed by the community in repeated discussions, followed by some leaders of the opposition being detained to deter the community from being involved in further oppositions, the authorities managed to reach an agreement with the community. The discussions involved promises about the inclusivity of the conversion process and the issuance of title deeds for their residential holdings. While $15 \%$ of the interlocutors felt they were tenure secure. These farmers include those who are working in the qebelé as members of the community development committee, those who did not have farmland or those who were given title deeds for their residential holdings.

In the case of Bole Arabsa and Cheri, all 33 farmers interviewed felt tenure insecure because they knew that they would lose their remaining land for the subsequent urban developments and that they were going to be evicted, they only did not know when. Most of the farmers in these areas have already lost part of their land to large housing projects and other urban utility projects. They knew that they would give up their remaining land when further urban development projects were initiated in the area. The data indicate that the source of insecurity in the two cities are different. In Chefe, there is uncertainty of the duration of holding rights; farmers fear losing their land holdings especially their agricultural land upon the inclusion of the land in to the city territory, and the fear of losing part or all of their residential land for the subsequent urban local development plan. In Bole-Arabsa and Cheri, farmers are certain about losing their land, but they do not know when that will occur. According to one of the respondents, " ... woreda authorities come unexpectedly with a surprise to measure and tell the land needed for a particular development project. They might come today or tomorrow, or a year after. As per our experience, they do not give us prior notice. We are always in a standby state; we cannot oppose their decision. If we do, we are done! We will be given this name 'development saboteur' followed by threatening, or abuse by officials or exclusion from any benefit scheme or detention." Most interlocutors view urban expansion as a threat to their land holding rights, causing insecurity as they anticipate expropriation and their own eviction justified by the government's power of taking land for urban utility. 
The data do not provide conclusive support to the notion that formalization of land rights guarantees tenure security, as claimed by De Soto [57] and other proponents of formalization. Hence, these findings reaffirm Rahmato's [34] argument, which states formalization of land right in the form of certificate cannot guarantee tenure security especially in a country where the state exercise unrestricted and unnegotiated authority of land taking and the land rights conferred are incomplete. Specifically, it cannot guarantee tenure security in a context such as the peri-urban areas where the state authority to take land is more active due to the enabling continuum of land use change from rural to urban. Therefore, legal land title by its own cannot be a standalone tool to measure tenure security especially in a peri-urban context where there are different forces driving the insecurityurbanization, non-inclusive urban development strategy, lack of pre-determined land use plan, unlimited state authority to take land and the incompleteness of the land rights. As indicated earlier, the study sites are distinct with regard to land right formalization; in Bole-Arabsa and Cheri, formalization of land rights has not taken place. The justification from the government's perspective was the inclusion of the areas into the city territory before the actual implementation of the registration and certification process. Therefore, farmers in the areas do not have land holding certificates. Whereas, in Chefe the land right formalization process has taken place and farmers have first level land certificate for their holdings. However, similar to the farmers in Bole-Arabsa and Cheri, farmers in Chefe also feel tenure insecure. The condition in the peri-urban areas reveals that the pressure from urbanization and the land acquisition decisions by the government have affected farmers perceived tenure security, which the ruling government promised to secure by enforcing the existing land tenure system, and through registration and certification of land rights. This is a contradiction to the very theory of formalization of land rights and it poses a question regarding the effectiveness of formalization of land rights in securing tenure.

\section{Conclusions}

This study of peri-urban Addis Ababa and Hawassa found that the condition of tenure in peri-urban areas varied based on the method of measurement employed to assess tenure security. By using perception indicators, the study found that peri-urban farmers in both cities feel tenure insecure. However, the cause of their insecurity is distinct, emanating from the nature of their respective peri-urban character. The finding has provided contradicting evidence to the claim that land right formalization will contribute to ensure tenure security. Peri-urban farmers with formalized land rights in Hawassa feel tenure insecure as the peri-urban farmers in Addis Ababa, whose land rights are not formalized. However, in both cases, peri-urban farmers identified urban expansion as the main source and driving force of their insecurity, as it involves constant change in land holding arrangements, accompanied by expropriation. Therefore, legal land title by its own cannot be a standalone tool to measure tenure security, especially for a peri-urban context where there are different driving forces of insecurity.

This study also proved that the quantity of rights landholders exercise does not always and necessarily interpret into tenure security. There is an assumption shared by most scholars that, the thicker the bundle of rights, the more tenure secure the holder of the property is. However, although farmers in peri-urban Hawassa exercise thicker bundle of rights over their land as compared to farmers in peri-urban Addis Ababa and farmers under the rural land holding system, the data from the perception indicator reveal that they are tenure insecure. Since the urbanization process is occurring at an alarming rate, farmers are quite sure that their land (at least the agricultural land) is going to be taken for urban utility. Conversely, the perceived tenure security cannot in depth show us the level of tenure insecurity, especially if someone is engaged in comparing two or more places and wants to know the extent of insecurity. Thus, by applying the real tenure security as measured by the actual land rights farmers exercise, and the change in the benefit streams, one can capture the distinctive tenure insecurity and land rights issues between different settings. Accordingly, it is evident from the findings that the farmers in peri-urban Addis 
Ababa are more tenure insecure as compared to peri-urban Hawassa. Farmers in peri-urban Addis Ababa hold fewer rights in the bundle having the weak claimant position, while in peri-urban Hawassa, farmers are in a better position of weak owner.

This result of the real tenure security, as measured by the range of holding rights, by and large depend on the urban development and expansion strategies adopted by the respective city administrations and the resulting definitional element of peri-urban areas. As discussed earlier, though its legality and effectiveness are debatable the relative inclusive strategy adopted by Hawassa city administration and the resulting definitional element has helped the peri-urban farmers to enjoy a better holding position of weak owner. In this regard, the regularization campaign that started in 2015 resulted in a positive change in the benefit streams by adding certain rights into the bundle. Whereas, the more restrictive urban development strategy in Addis Ababa employed and the determination of the peri-urban areas as expansion zones created conditions where peri-urban farmers hold a lesser position of weak claimant. The restrictive urban development strategy in Addis Ababa resulted in a negative change in the benefit stream by cutting certain rights from the bundle.

As urbanization is an ongoing and expanding phenomenon, taking place in every corner of the country, it is important to assess the rights and conditions appropriately, lest certain types of evidence misinform policy makers, enabling improper policy responses and development strategies. This study has demonstrated that the issues of peri-urban farmers call for subjective and reality-based interventions that are based on research conducted using the right techniques of measurement. Additionally, the findings of this study provide evidence that calls for the revision of the regulatory system related to land tenure and the adoption of a more inclusive and responsive urban development strategy, which takes in to consideration the land rights and livelihood desire of peri-urban farmers. Finally, the findings of this study provide evidence and foundation for further academic research, focusing on how the peri-urban farmers land rights be formally recognized and integrated in the urban development processes taking place in Ethiopia.

Author Contributions: Conceptualization, A.T.T.; methodology, A.T.T.; validation, L.C.; formal analysis, A.T.T.; writing-original draft preparation, A.T.T.; writing-review and editing, L.C.; supervision, L.C.; project administration, A.T.T. All authors have read and agreed to the published version of the manuscript.

Funding: This research was partially funded by a NORAD-DEG project, which provided provided for the doctoral program that A.T.T. participated in.

Institutional Review Board Statement: The study was conducted according to the guidelines of the Declaration of Helsinki and was reviewed and approved by Hawassa University, as part of the doctoral studies of A.T.T.

Informed Consent Statement: Informed consent was obtained from all subjects involved in the study.

Acknowledgments: This article was developed from an ongoing PhD research project at IPDR, Hawassa University, which is funded by a NORAD-DEG project. This research was presented as a conference paper at the 20th International Conference of Ethiopian Studies: Regional and Global Ethiopia-Interconnections and Identities under the panel "Land of the future. Time for innovation. Can Ethiopia still set a global example for equitable development?"

Conflicts of Interest: There is no conflict of interest. The funders had no role in the design of the study; in the collection, analyses, or interpretation of data; in the writing of the manuscript, or in the decision to publish the results.

\section{References}

1. Djiré, M. The rush for peri-urban lands-Another matter of worry for land governance in West Africa: A case study in Mali. In Proceedings of the Annual World Bank Conference on Land and Poverty, Washington, DC, USA, 8-11 April 2013.

2. Toulmin, C. Securing land and property rights in sub-Saharan Africa: The role of local institutions. Land Use Policy 2009, 26, 10-19. [CrossRef] 
3. United Nation Human Settlement Programme. The State of African Cities 2010: Governance, Inequality and Urban Land Markets; UN-HABITAT: Nairobi, Kenya, 2010.

4. Wehrmann, B. The dynamics of peri-urban land markets in sub-Saharan Africa: Adherence to the virtue of common property vs. quest for individual gain (Die Dynamik peri-urbaner Bodenmärkte in Afrika südlich der Sahara: Festhalten an den Vorteilen des Gemeinschaftseigentums vs. Streben nach individuellem Gewinn). Erdkunde 2008, 62, 75-88.

5. Adam, A.G. Informal settlements in the peri-urban areas of Bahir Dar, Ethiopia: An institutional analysis. Habitat Int. 2014, 43, 90-97. [CrossRef]

6. Adam, A.G. Peri-urban land rights in the era of urbanisation in Ethiopia: A property rights approach. Afr. Rev. Econ. Financ. 2014, 6, 120-138.

7. Agegnehu, S.K.; Fuchs, H.; Navratil, G.; Stokowski, P.; Vuolo, F.; Mansberger, R. Spatial Urban Expansion and Land Tenure Security in Ethiopia: Case Studies from Bahir Dar and Debre Markos Peri-Urban Areas. Soc. Nat. Resour. 2015, 29, 311-328. [CrossRef]

8. Eniyew, S. Debre Tabor University Mapping urban expansion and its effect on the surrounding land uses using GIS and remote sensing. A case study in Debre Tabor Town, Ethiopia. J. Degrad. Min. Lands Manag. 2018, 6, 1427-1439. [CrossRef]

9. Kasa, L. Impact of Urbanization of Addis Ababa City on Peri-Urban Environment and Livelihoods. Ph.D. Thesis, Haramaya University, Haramaya, Ethiopia, 2011.

10. Wubneh, M. Policies and praxis of land acquisition, use, and development in Ethiopia. Land Use Policy 2018, 73, 170-183. [CrossRef]

11. Mulwanda, M.P. The socio-economic consequences of squatter clearance and relocation in Zambia. Afr. Urban Q. 1989, 4, 254-261.

12. Payne, G.; Durand-Lasserve, A. Holding on: Security of Tenure-Types, Policies, Practices and Challenges. Research Paper Prepared for the Special Rapporteur on Adequate Housing as a Component of the Right to An Adequate Standard of Living, and on the Right to Non-Discrimination. 2012. Available online: https://www.ohchr.org/Documents/Issues/Housing/SecurityTenure/ Payne-Durand-Lasserve-BackgroundPaper-JAN2013.pdf (accessed on 21 October 2017).

13. Rakodi, C.; Gatabaki-Kamau, R.; Devas, N. Poverty and political conflict in Mombasa. Environ. Urban. 2000, 12, 153-170. [CrossRef]

14. Mbiba, B.; Huchzermeyer, M. Contentious development: Peri-urban studies in sub-Saharan Africa. Prog. Dev. Stud. 2002, 2, 113-131. [CrossRef]

15. Tibaijuka, A.K. Security of tenure in urban Africa. In Proceedings of the Land in Africa Market Asset or Secure Livelihood, London, UK, 8-9 November 2004; pp. 99-103.

16. Allen, A.; Dávila, J.D.; Hofmann, P. The peri-urban water poor: Citizens or consumers? Environ. Urban. 2006, 18, 333-351. [CrossRef]

17. Dupont, V. Peri-Urban Dynamics: Population, Habitat and Environment on the Peripheries of Large Indian Metropolises: A Review of Concepts and General Issues; Centre de Sciences Humaines: New Delhi, India, 2005.

18. Halkatti, M.; Purushothaman, S.; Brook, R. Participatory action planning in the peri-urban interface: The twin city experience, Hubli-Dharwad, India. Environ. Urban. 2003, 15, 149-158. [CrossRef]

19. Simon, D.; MacGregor, D.; Nsiah-Gyabaah, K.; Thompson, D. Poverty Elimination, North-South Research Collaboration, and the Politics of Participatory Development. Dev. Pract. 2003, 13, 40-56. [CrossRef]

20. Freidberg, S.E. Gardening on the Edge: The Social Conditions of Unsustainability on an African Urban Periphery. Ann. Assoc. Am. Geogr. 2001, 91, 349-369. [CrossRef]

21. Belay, E. Impact of urban expansion on the agricultural land use-a remote sensing and GIS approach: A case of Gondar city, Ethiopia. Int. J. Innov. Res. Devel. 2014, 3, 129-133.

22. Admasu, T.G. Urban land use dynamics, the nexus between land use pattern and its challenges: The case of Hawassa city, Southern Ethiopia. Land Use Policy 2015, 45, 159-175. [CrossRef]

23. Adam, A.G. Land Tenure in the Changing Peri-Urban Areas of Ethiopia: The Case of Bahir Dar City. Int. J. Urban Reg. Res. 2014, 38, 1970-1984. [CrossRef]

24. UN-HABITAT. The state of Addis Ababa, 2017: The Addis Ababa We Want; UN-HABITAT: Nairobi, Kenya, 2017.

25. World Bank Group. Ethiopia-Urbanization Review: Urban Institutions for a Middle-Income Ethiopia; World Bank Group: Washington, DC, USA, 2015.

26. Schlager, E.; Ostrom, E. Property-Rights Regimes and Natural Resources: A Conceptual Analysis. Land Econ. 1992, 68, 249. [CrossRef]

27. Guest, G.; Namey, E.E.; Mitchell, M.L. Collecting Qualitative Data: A Field Manual for Applied Research; SAGE Publications: Thousand Oaks, CA, USA, 2013.

28. Zewde, B. A history of modern Ethiopia, 1855-1991; Ohio University Press: Athens, USA, 2002.

29. Ambaye, D.W. Land Rights and Expropriation in Ethiopia. Ph.D. Thesis, Royal Institute of Technology (KTH), Stockholm, Sweden, 2013.

30. Crewett, W.; Korf, B. Ethiopia: Reforming Land Tenure. Rev. Afr. Politi-Econ. 2008, 35, 203-220. [CrossRef]

31. Gebreamanuel, D.B. Transfer of Land Rights in Ethiopia: Towards a Sustainable Policy Framework; Eleven International Publishing: The Hague, The Netherlands, 2015. 
32. Adal, Y. Some queries about the debate on land tenure in Ethiopia. In Proceedings of the Tenth Annual Conference on the Ethiopian Economy, Nazeret, Ethiopia, 3-5 November 2000. EEA.

33. Pankhurst, A.; Dessalegn, M.; Mueller, V.; Hailemariam, M. Migration and resettlement: Reflections on trends and implica-tions for food security. In Food Security, Safety Nets and Social Protection in Ethiopia; Forum for Social Studies: Addis Ababa, Ethiopia, 2013.

34. Rahmato, D. The Peasant and the State: Studies in Agrarian Change in Ethiopia 1950s-2000s; Custom Books: Addis Ababa, Ethiopia, 2009.

35. Ethiopian Economic Association. Land Tenure and Agricultural Development in Ethiopia; Ethiopian Economic Association: Addis Ababa, Ethiopia, 2002.

36. Holden, S.T.; Bezu, S. Preferences for land sales legalization and land values in Ethiopia. Land Use Policy 2016, 52, 410-421. [CrossRef]

37. Rahmato, D. Land policy in Ethiopia at the crossroads. In Land Tenure and Land Policy in Ethiopia after the Derg; University of Tronheim: Trondheim, Norway, 1994.

38. Crewett, W.; Bogale, A.; Korf, B. Land Tenure in Ethiopia: Continuity and Change, Shifting Rulers, and the Quest For State Control. AgEcon Search 2008. [CrossRef]

39. FDRE Constitution. The Constitution of the Federal Democratic Republic of Ethiopia (FDRE) Proclamation No 1/1995, Federal Negarit Gazetta, No. 1. 1995; FDRE: Addis Ababa, Ethiopia, 1995.

40. Cochrane, L.; Hadis, S. Functionality of the land certification program in Ethiopia: Exploratory evaluation of the processes of updating certificates. Land 2019, 8, 149. [CrossRef]

41. FAO. Land Tenure and Rural Development; FAO: Rome, Italy, 2002.

42. GLTN/UN-Habitat. Secure Land Rights for All; GLTN/UN-Habitat: Nairobi, Ethiopia, 2008.

43. Bromley, D.W. Environment and Economy: Property Rights and Public Policy; Basil Blackwell: Oxford, UK, 1991.

44. Alchian, A.A.; Demsetz, H. The Property Right Paradigm. J. Econ. Hist. 1973, 33, 16-27. [CrossRef]

45. Arnot, C.D.; Luckert, M.K.; Boxall, P.C. What Is Tenure Security? Conceptual Implications for Empirical Analysis. Land Econ. 2011, 87, 297-311. [CrossRef]

46. Besley, T. Property Rights and Investment Incentives: Theory and Evidence from Ghana. J. Politi-Econ. 1995, 103, 903-937. [CrossRef]

47. Owubah, C.E.; Le Master, D.C.; Bowker, J.; Lee, J.G. Forest tenure systems and sustainable forest management: The case of Ghana. For. Ecol. Manag. 2001, 149, 253-264. [CrossRef]

48. Place, F.; Hazell, P. Productivity Effects of Indigenous Land Tenure Systems in Sub-Saharan Africa. Am. J. Agric. Econ. 1993, 75, 10-19. [CrossRef]

49. Sjaastad, E.; Bromley, D.W. The Prejudices of Property Rights: On Individualism, Specificity, and Security in Property Regimes. Dev. Policy Rev. 2000, 18, 365-389. [CrossRef]

50. Holden, S.; Yohannes, H. Land Redistribution, Tenure Insecurity, and Intensity of Production: A Study of Farm Households in Southern Ethiopia. Land Econ. 2002, 78, 573-590. [CrossRef]

51. Place, F.; Roth, M.; Hazell, P. Land tenure security and agricultural performance in Africa: Overview of research methodology. In Searching for Land Tenure Security in Africa; Bruce, S.E., Migot-Adholla, S.E., Eds.; Kendall/Hunt: Dubuque, Iowa, 1994; pp. 15-39.

52. Smith, R.E. Land Tenure, Fixed Investment, and Farm Productivity: Evidence from Zambia's Southern Province. World Dev. 2004, 32, 1641-1661. [CrossRef]

53. Bruce, J.W.; Migot-Adholla, S.E. Searching for Land Tenure Security in Africa; Kendall/Hunt: Dubuque, Iowa, 1994.

54. André, J.H.; Ubink, J.M.; Assies, W.J. Legalising Land Rights. Local Practices, State Responses and Tenure Security in Africa, Asia and Latin America; Leiden University Press: Leiden, The Netherlands, 2009.

55. Lund, C. African Land Tenure: Questioning Basic Assumptions; International Institute for Environment and Devel-opment: London, $\mathrm{UK}, 2000$.

56. Brasselle, A.-S.; Gaspart, F.; Platteau, J.-P. Land tenure security and investment incentives: Puzzling evidence from Burkina Faso. J. Dev. Econ. 2002, 67, 373-418. [CrossRef]

57. De Soto, H. The Mystery of Capital: Why Capitalism Triumphs in the West and Fails Everywhere Else; Basic Books: New York, NY, USA, 2000 .

58. Deininger, K.; Ali, D.A.; Alemu, T. Impacts Of Land Certification On Tenure Security, Investment, And Land Markets: Evidence From Ethiopia; The World Bank: Washington, DC, USA, 2008.

59. Deininger, K.W. Land Policies for Growth and Poverty Reduction; World Bank Publications: Washington, DC, USA, 2003.

60. Mwangi, E. Subdividing the Commons: Distributional Conflict in the Transition from Collective to Individual Property Rights in Kenya's Maasailand. World Dev. 2007, 35, 815-834. [CrossRef]

61. Place, F.; Otsuka, K. Population Pressure, Land Tenure, and Tree Resource Management in Uganda. Land Econ. 2000, 76, 233. [CrossRef]

62. Feder, G.; Noronha, R. Land rights systems and agricultural development in sub-saharan Africa. World Bank Res. Obs. 1987, 2, 143-169. [CrossRef]

63. Deacon, R.T. Deforestation and the Rule of Law in a Cross-Section of Countries. Land Econ. 1994, 70, 414. [CrossRef] 
64. Feder, G.; Onchan, T. Land Ownership Security and Farm Investment in Thailand. Am. J. Agric. Econ. 1987, 69, 311-320. [CrossRef]

65. Feder, G.; Onchan, T.; Chalamwong, Y. Land Policies and Farm Performance in Thailand's Forest Reserve Areas. Econ. Dev. Cult. Chang. 1988, 36, 483-501. [CrossRef]

66. Razzaz, O.M. Examining Property Rights and Investment in Informal Settlements: The Case of Jordan. Land Econ. 1993, 69, 341. [CrossRef]

67. Cole, D.H.; Ostrom, E. The Variety of Property Systems and Rights in Natural Resources. SSRN Electron. J. 2010, 2, 123-160. [CrossRef]

68. Abbink, J. Discomfiture of democracy? The 2005 election crisis in Ethiopia and its aftermath. Afr. Aff. 2006, 105, 173-199. [CrossRef]

69. Kinfu, E.; Cochrane, L. 'What makes our land illegal?' 'Regularization' and the urbanization of rural land in Ethiopia. In The RIght to be Rural: Citizenship Outside the City; Foster, K., Jarman, J., Eds.; University of Alberta Press: Edmonton, AB, Canda, 2021.

70. Kinfu, E.; Bombeck, H.; Nigussie, A.; Wegayehu, F. The Genesis of Peri-urban Ethiopia: The Case of Hawassa City. J. Land Rural Stud. 2019, 7, 71-95. [CrossRef] 